Nancy Bell

We Are Not Amused 


\section{Humor Research}

Editors

Victor Raskin

Willibald Ruch

Volume 10 


\section{Nancy Bell}

\section{We Are Not \\ Amused}

Failed Humor in Interaction

\section{DE GRUYTER}

MOUTON 
An electronic version of this book is freely available, thanks to the support of libraries working with Knowledge Unlatched. $\mathrm{KU}$ is a collaborative initiative designed to make high quality books Open Access. More information about the initiative can be found at www.knowledgeunlatched.org

\section{(cc) BY-NC-ND}

This work is licensed under the Creative Commons Attribution-NonCommercial-NoDerivs 4.0 License. For details go to http://creativecommons.org/licenses/by-nc-nd/4.0/.

ISBN 978-1-5015-1052-6

e-ISBN (PDF) 978-1-5015-0158-6

e-ISBN (EPUB) 978-1-5015-0164-7

ISSN 1861-4116

\section{Library of Congress Cataloging-in-Publication Data}

A CIP catalog record for this book has been applied for at the Library of Congress.

\section{Bibliographic information published by the Deutsche Nationalbibliothek}

The Deutsche Nationalbibliothek lists this publication in the Deutsche Nationalbibliografie; detailed bibliographic data are available on the Internet at http://dnb.dnb.de.

(C) 2015 Walter de Gruyter, Inc., Berlin/Boston/Munich

Typesetting: PTP-Berlin, Protago- $\mathrm{T}_{\mathrm{E}} \mathrm{X}$-Production $\mathrm{GmbH}$, Berlin

Printing and binding: $\mathrm{CPI}$ books $\mathrm{GmbH}$, Leck

(2) Printed on acid-free paper

Printed in Germany

www.degruyter.com 